\title{
Black Edible Films from Protein-Containing Defatted Cake of Nigella sativa Seeds
}

\author{
Mohammed Sabbah ${ }^{1}\left(\mathbb{D}\right.$, Mohammad Altamimi $^{1}\left(\mathbb{D}\right.$, Prospero Di Pierro $^{2}\left(\mathbb{D}\right.$, Chiara Schiraldi $^{3} \mathbb{( D}$, \\ Marcella Cammarota ${ }^{3}$ and Raffaele Porta ${ }^{2, * \text { (ID }}$ \\ 1 Department of Nutrition and Food Technology, An-Najah National University, Nablus P.O. Box: 7, Palestine; \\ m.sabbah@najah.edu (M.S.); m.altamimi@najah.edu (M.A.) \\ 2 Department of Chemical Sciences, University of Naples "Federico II", 80126 Naples, Italy; dipierro@unina.it \\ 3 Department of Experimental Medicine, Section of Biotechnology and Molecular Biology, \\ University of Campania “Luigi Vanvitelli”, 80138 Naples, Italy; chiara.schiraldi@unicampania.it (C.S.); \\ marcella.cammarota@unicampania.it (M.C.) \\ * Correspondence: raffaele.porta@unina.it; Tel.: +39-081-2539-473
}

Received: 9 December 2019; Accepted: 26 January 2020; Published: 28 January 2020

check for updates

\begin{abstract}
Black biodegradable/edible protein-based films were prepared from defatted cake waste obtained from Nigella sativa (black cumin) seeds as by-product of oil extraction process. The effects of $\mathrm{pH}$, glycerol concentrations, and transglutaminase-catalyzed protein cross-linking activity on the stability of film-forming solutions were studied to determine the best experimental conditions to produce handleable films. Proteins contained in the analyzed defatted cake were shown to be able to act as transglutaminase acyl donor and acceptor substrates being polymerized when incubated in vitro in the presence of the enzyme. Film-forming solutions containing $20 \%$ glycerol and casted at $\mathrm{pH} 8.0$ after treatment with the enzyme gave rise to morphologically more homogeneous films possessing mechanical and barrier properties, as well as antimicrobial activity, compatible with their possible applications as food packaging materials and mulching sheets. These findings confirm the validity of the strategy to consider the seed oil processed cakes as protein-based renewable sources to produce not only fertilizers, animal feed, or culinary food but also further valuable products such as bioplastics.
\end{abstract}

Keywords: Nigella sativa; protein-based films; industrial biorenewables; oil-seed waste; transglutaminase

\section{Introduction}

It is now generally recognized that the environmental pollution due to plastic polymers is a global concern. Landfills and oceans are the main destination of the plastic waste, whereas only less than $10 \%$ of plastics produced every year is recycled [1]. Seeking biodegradable alternatives for plastics is increasing, even though they still probably represent less than $5 \%$ of the total plastic materials used today.

For the food industry, packaging is an important process to protect food items from the external environment and to extend their shelf life. Packaging materials are an effective barrier against light, heat, moisture, gases, and microorganisms, as well as they prevent loss of flavors and aromas. Oil-derived plastics, mostly thanks to their versatile characteristics of stability, flexibility, rigidity, transparency, and molding, have been and continue to be extensively used to protect the majority of the commercialized foods. Plastic packaging wastes represent more than $15 \%$ and $25 \%$ of total solid wastes in the USA and Europe, respectively [2]. Nevertheless, both the demand and the production for new biodegradable packaging materials able to substitute for the traditional plastic ones are on the rise [1]. 
The current focus of many researchers is on the use of bio-polymers obtained from agri-food by-products as potential alternatives to fossil-based polymers. These biomacromolecular sources are not only safe for humans but also environmentally friendly due to their biodegradability. Numerous food industry wastes, such as citrus peels, cassava by-products, and apple pomace, as well as whey, have been already proposed as possible biodegradable sources to produce alternative materials useful for food packaging [3-7].

Different seeds are widely used to produce vegetable oils or animal feed. Those from soy, sesame, and bitter vetch have been shown to be potential sources of biodegradable/edible films [8-12]. In fact, after oil extraction, the leftover cakes may contain up to $50 \%$ recyclable proteins that may produce bio-materials. Moreover, the defatted seed wastes generally contain a high level of polyphenols and, thus, they may even act as antioxidants and antimicrobials inside the derived edible films used as food coatings or wrappings. Consequently, the packaged food products are preserved from deterioration (rancidity, oxidation, and spoilage by microorganisms). This may increase the total polyphenols ingested by the consumer giving an additional nutritional contribution of these films $[13,14]$.

Nigella sativa (black cumin), belonging to Ranunculaceae family, is cultivated in various parts of the world and, in particular, is widely grown in the Middle East countries [15]. It is a bushy, self-branching plant with either white or pale to dark blue flowers [16]. Its seeds are mainly used as condiment, while the extracted oil is exploited in traditional medicine for the treatment of a wide range of diseases. Seed composition varies from one geographical area to another, mainly because of the different environmental factors and horticultural practices. On average, the seeds contain $21 \%$ proteins, $35 \%$ fat, $29 \%$ carbohydrates, $6 \%$ crude fibers, $5 \%$ moisture, and $4 \%$ ash [15].

Although several researches have been performed to study the benefits of Nigella sativa seeds, roots, and shoots, only few data are available on the bioactivity of its seed cake and, among these, the high antioxidant activity probably due to the predominant phenolic compounds (hydroxybenzoic, syringic, and p-coumaric acids) [17]. Nigella sativa seeds have been in use for 3000 years, but the precise global consumption of them, as well as of the extracted oil, is not known. It is estimated that India alone produces $85 \%$ of the world's cumin (brown and black), with 250,000 metric tons/year, followed by Middle Eastern countries including Syria, Turkey, and Egypt. Major importers are Asian-Pacific countries, North America, EU, South Africa, and Middle Eastern countries. In addition to the seeds, also the extracted oil is exported worldwide [18].

With the increasing awareness about its therapeutic benefits, the demand on black cumin oil is rising. Few bioactive compounds extracted from Nigella sativa seeds have been identified, the most important being the thymoquinones [19]. Other phytochemicals from different varieties of Nigella sativa include sterols, saponins, phenolic compounds, various alkaloids, some lipid constituents, and fatty acids, as well as volatile oils of different composition [20]. Furthermore, the most important compounds responsible for seed pigmentation are phytomelanins, high-molecular weight polymers formed by the oxidation of phenols [21-23]. It has been highlighted that the black coated seeds survive for years under the soil and are resistant to soil acidity, insect predators, and microbial attack.

Currently, to the authors' knowledge, there is no report about the amount of black cumin seeds utilized for oil extraction. Large quantities of defatted cake is certainly generated as by-product and most of it is offered as animal feed due to the high protein content [24]. Moreover, there are no reports in the literature about the exploitation of the proteins extracted from Nigella sativa defatted seed cake (NsDSC) to obtain novel bio-materials.

In this study, black films were prepared from a protein concentrate (PC) derived from NsDSC, in the presence of glycerol (GLY) as plasticizer, and their characterization was carried out. Furthermore, the effect of transglutaminase (TGase), a food-grade protein cross-linking enzyme used as processing aid [25-27], was also investigated in the attempt to improve the functional properties of the obtained biodegradable/edible material. 


\section{Results and Discussion}

\subsection{FFS Zeta Potential and Z-Average Measurements}

Zeta potential, a quantitative parameter monitoring the micro- and nano-particle mobility in an electrical field, as well as the size of the particles occurring in aqueous solution of PC obtained from NsDSC, were preliminarily determined as a function of $\mathrm{pH}$ to find proper conditions for the development of stable film-forming solutions (FFSs) [28]. The zeta potential of NsDSC-derived proteins showed a value ranging from $-45 \mathrm{mV}$ to $-41 \mathrm{mV}$ between $\mathrm{pH} 12.0$ and 8.0 (Figure 1, upper panel), whereas the value was found to progressively decrease to $-27 \mathrm{mV}$ and $-5 \mathrm{mV}$ with lower $\mathrm{pH} 6.0$ and 5.0 , respectively, then becoming positive under $\mathrm{pH} 4.0$. Therefore, these findings clearly suggested to prepare protein FFSs at pH values no lower than 6.0 in order to obtain stable solutions. This indication was also confirmed by the Z-average size of the protein particles which lost their nano-dimension under $\mathrm{pH} 6.0$ reaching at lower $\mathrm{pHs}$ a Z-average value over 1000 d.nm (diameter nanometers) (Figure 1, lower panel).

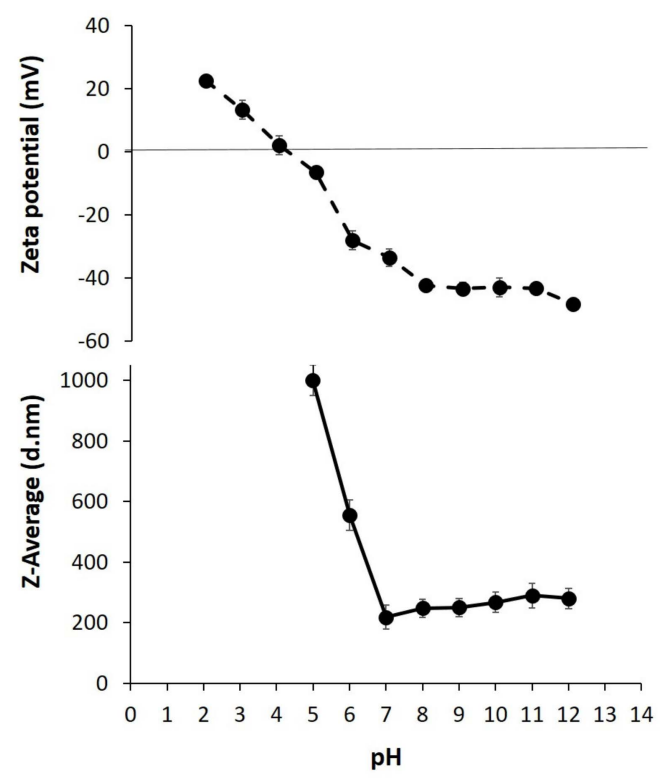

Figure 1. Zeta potential (upper panel) and Z-average size (lower panel) measurements of Nigella sativa defatted seed cake (NsDSC)-derived protein concentrate (PC) performed at different $\mathrm{pH}$ values. PC sample contained $1.0 \mathrm{mg}$ protein dissolved in $1.0 \mathrm{~mL}$ of distilled water at $\mathrm{pH} 12$. All the results were reported as mean \pm standard deviation. Further experimental details are given in the text.

\subsection{NsDSC Proteins as TGase Substrates}

It was previously demonstrated that different seed proteins were able to act as TGase substrates $[8,11,12,29,30]$. Therefore, we verified whether one or more proteins occurring in PC obtained from NsDSC were able to be cross-linked during incubation at $37^{\circ} \mathrm{C}$ for $2 \mathrm{~h}$ at $\mathrm{pH} 8.0$ in the presence of different amounts of the enzyme. Aliquots of reaction mixtures were then analyzed by SDS-PAGE and the extent of the enzymatic protein cross-linking was evaluated observing the progressive decrease of intensity of the Coomassie-stained bands occurring in the electrophoretic protein profiles. Reaction mixtures prepared in the absence of TGase were also incubated to confirm the enzyme-dependent polymer formation. As shown in Figure 2, a progressive attenuation of all proteins contained in the NsDSC was observed when the reaction mixtures were incubated in the presence of increasing concentrations of TGase, while a concomitant formation of high mol. wt. polymers became detectable at the top of the gel. These results indicate that, similarly to other seed proteins $[8,11,31]$, both glutamine and lysine reactive residues able to give rise to cross-linked homo- 
and/or hetero-polymers in the presence of the enzyme were present into the proteins contained in NsDSC.

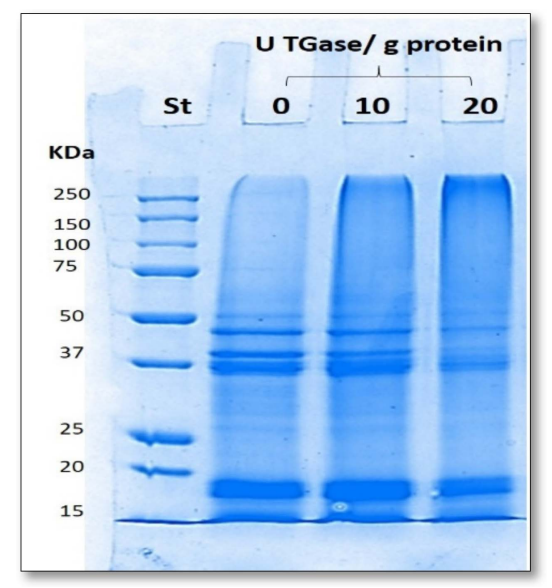

Figure 2. SDS-PAGE profile of film forming solutions (FFSs) previously incubated in the absence or presence of two different amounts of transglutaminase (TGase). Further experimental details are given in the text.

Finally, experiments aimed to find adequate conditions for the development of solutions able to give rise to plasticized films were carried out in the presence of different concentrations of GLY. Thus, both zeta potential and Z-average of FFSs, containing PC previously incubated in the absence or presence of TGase, were measured after GLY addition. The results reported in Figure 3 show that neither GLY nor enzymatic treatment significantly influenced FFS zeta potential, whereas the Z-average values slightly increased in the samples previously incubated with TGase, independently on the presence of GLY, probably as a consequence of protein cross-linking.
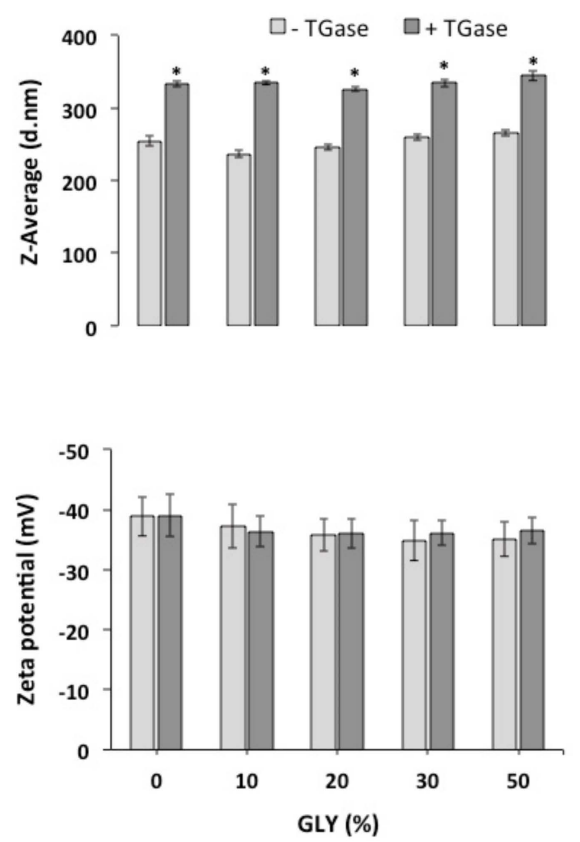

Figure 3. Z-Average and zeta potential, measured at $\mathrm{pH} 8.0$, of protein concentrate (PC, $400 \mathrm{mg}$ ) FFSs containing different concentrations of glycerol (GLY) after incubation in the absence or presence of transglutaminase (TGase, 20 Units/g protein). Further experimental details are given in the text. * Significantly different values as compared to the ones obtained under the same experimental conditions in the absence of TGase $(p<0.05)$. 


\subsection{Black Edible Films from PC of NsDSC}

PC FFSs either containing different GLY amounts or prepared at different $\mathrm{pH}$ values were incubated in the absence or presence of TGase and finally casted and dried for $48 \mathrm{~h}$. Figure 4 shows that handleable black films were obtained at $\mathrm{pH} 8.0$ by adding at least $10 \%$ GLY as plasticizer (panel A) and, in the presence of $20 \%$ GLY, at all the pHs between 6.0 and 12.0 (panel B).

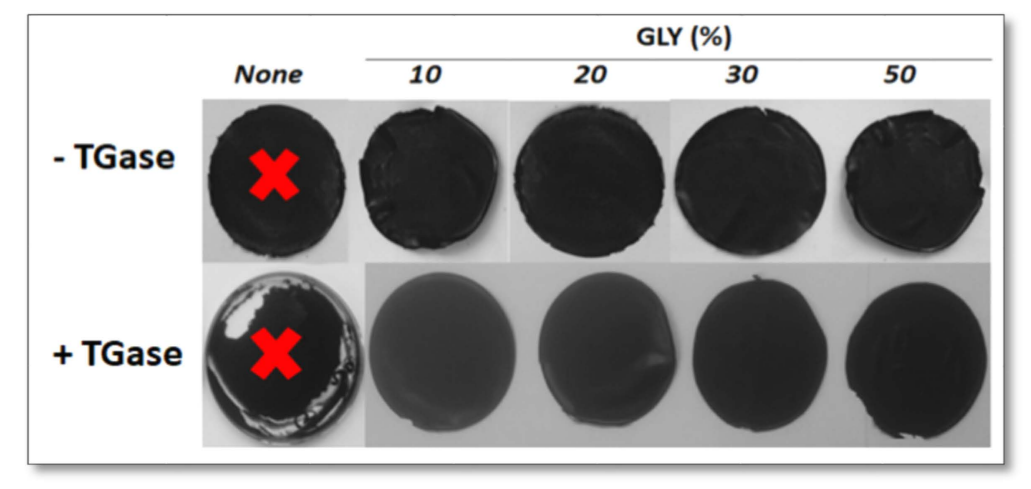

(A)

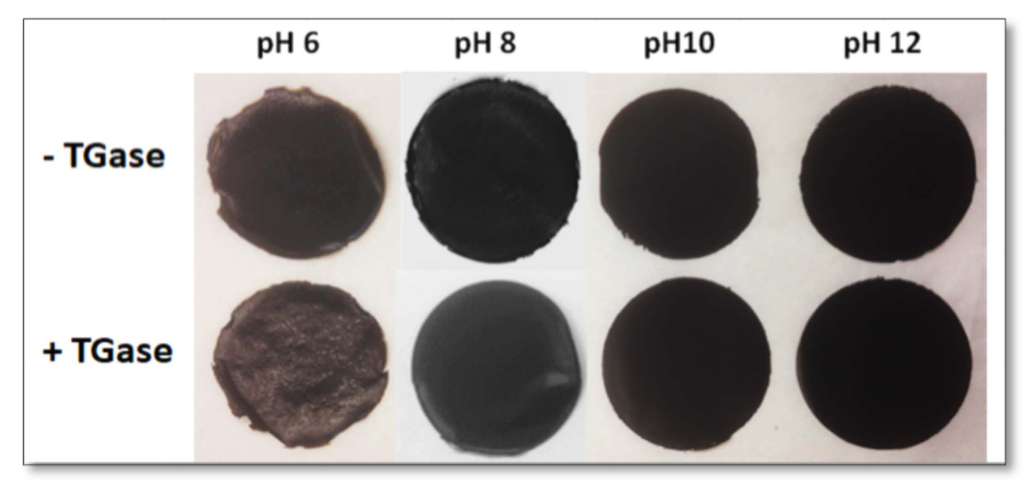

(B)

Figure 4. Images of protein concentrate (PC, $400 \mathrm{mg}$ ) films either containing different concentrations of glycerol (GLY) and obtained at pH 8.0 (A) or containing 20\% GLY and obtained at different $\mathrm{pH}$ values (B) after incubation of the FFSs in the absence or presence of transglutaminase (TGase, $20 \mathrm{U} / \mathrm{g}$ protein). Further experimental details are given in the text.

Figure 5 shows the effect of the different GLY concentrations on the mechanical properties of the films casted at $\mathrm{pH}$ 8.0, while Table 1 reports the same properties detected with films containing $20 \%$ GLY and casted at different pHs. Both experiments clearly indicate that the TGase-treated FFSs gave rise to significantly thicker films at all GLY concentrations and at all casting $\mathrm{pH}$ values. Moreover, the combined effects of $\mathrm{pH}$ and GLY concentrations resulted of particular interest. In fact, the addition of $20 \%$ GLY to FFS casted at $\mathrm{pH} 8.0$ generated a peculiar positive effect on the mechanical properties of the films obtained with the TGase-treated FFS, causing a significant increase in their tensile strength (TS) and elongation at break (EB), without changing the quite low value of Young's module (YM).

The high absorbance and low transmittance of both kinds of film at 200-550 nm wavelengths (Figure 6) may be considered a further interesting feature of the NsDSC-derived materials. In fact, they should be potentially able to hinder a possible photooxidative deterioration of the packaged foods and drugs by UV irradiation, as well as to suppress weeds and conserve water in crop production if used as biodegradable mulching sheets. Furthermore, a significant difference was also observed in the absorbance/transmittance intensity in the range of $550-800 \mathrm{~nm}$ of the films prepared from the FFS 
incubated in the presence of TGase with respect to those obtained from FFS incubated in the absence of enzyme. This result was probably due to the TGase-catalyzed change of the film protein network.

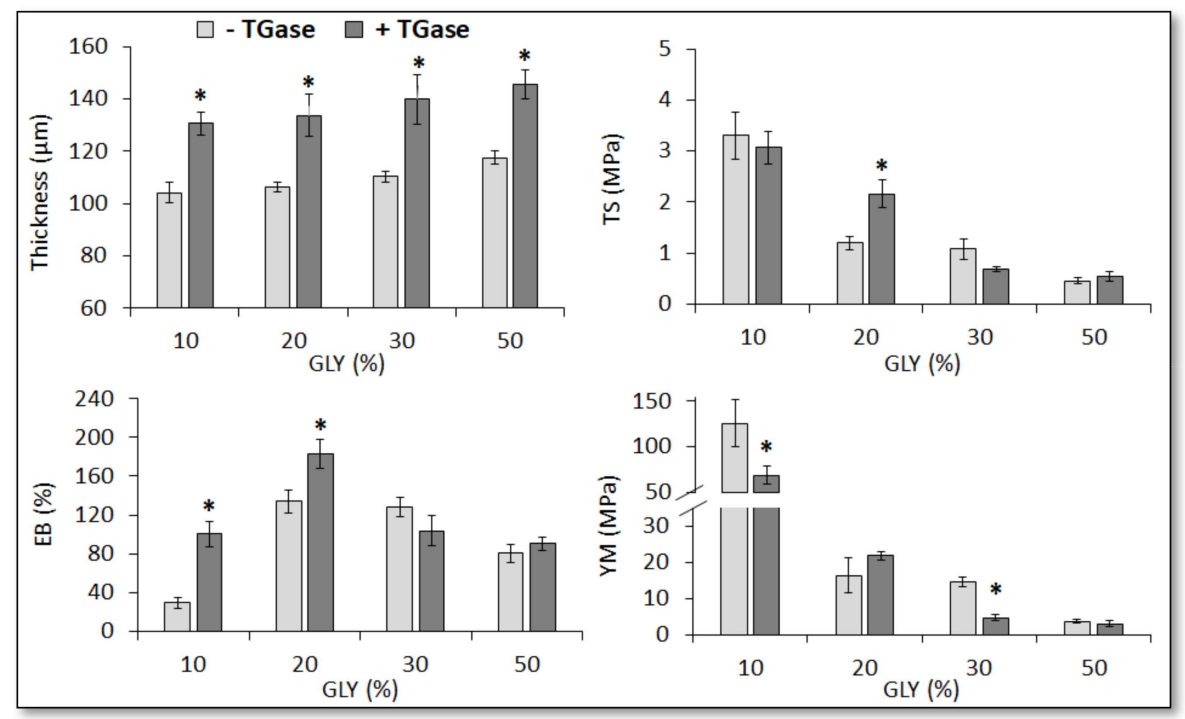

Figure 5. Effect of different concentrations of glycerol (GLY) on the mechanical properties (TS, tensile strength; EB, elongation at break; YM, Young's modulus) of protein concentrate (PC, $400 \mathrm{mg}$ ) films obtained at $\mathrm{pH} 8.0$ after incubation of FFSs in the absence or presence of transglutaminase (TGase, $20 \mathrm{U} / \mathrm{g}$ protein). Further experimental details are given in the text. * Significantly different values as compared to those obtained under the same experimental conditions in the absence of TGase $(p<0.05)$.

Table 1. Mechanical properties (TS, tensile strength; EB, elongation at break; YM, Young's modulus) of $20 \%$ glycerol (GLY)-containing protein concentrate (PC, $400 \mathrm{mg}$ ) films obtained at different $\mathrm{pH}$ values after film forming solution (FFS) incubation in the absence or presence of transglutaminase (TGase, $20 \mathrm{U} / \mathrm{g}$ protein). Further experimental details are given in the text.

\begin{tabular}{cccccc}
\hline Film & $\mathbf{p H}$ & Thickness $(\mu \mathrm{m})$ & TS $(\mathbf{M P a})$ & EB $(\%)$ & YM $(\mathbf{M P a})$ \\
\hline \multirow{5}{*}{ TGase } & 6.0 & $106.5 \pm 3.9$ & $1.2 \pm 0.2$ & $9.8 \pm 2.7$ & $94.4 \pm 5.0$ \\
& 10.0 & $107.5 \pm 2.8$ & $1.4 \pm 0.2$ & $130.4 \pm 8.4$ & $19.4 \pm 2.8$ \\
& 12.0 & $105.2 \pm 3.8$ & $1.3 \pm 0.3$ & $40.9 \pm 8.5$ & $45.4 \pm 3.5$ \\
& 6.0 & $135.0 \pm 8.4^{*}$ & $1.8 \pm 0.3$ & $16.4 \pm 3.2 *$ & $85.7 \pm 5.3$ \\
+ TGase & 8.0 & $134.9 \pm 8.4^{*}$ & $2.2 \pm 0.1 *$ & $183.5 \pm 8.5 *$ & $18.7 \pm 2.3$ \\
& 10.0 & $139.8 \pm 7.8^{*}$ & $1.8 \pm 0.2$ & $70.8 \pm 7.2 *$ & $38.9 \pm 4.6$ \\
& 12.0 & $131.6 \pm 7.3^{*}$ & $2.3 \pm 0.4$ & $61.0 \pm 3.8^{*}$ & $30.0 \pm 4.5 *$
\end{tabular}

* Significantly different values as compared to the ones obtained under the same experimental conditions in the absence of TGase $(p<0.05)$.

Therefore, we can conclude that the enzymatically cross-linked NsDSC-derived proteins may give rise at $\mathrm{pH} 8.0$, in the presence of $20 \% \mathrm{GLY}$, to biodegradable, resistant, and at same time flexible dark films, exploitable not only for food packaging but also for mulching. In fact, it is well known that plastic mulch disposal is a distinguished environmental concern [32]. The black color of the obtained film would help not only to protect packaged drugs or food products from a variety of photooxidative agents, but also in the agriculture if used as mulching sheet.

The permeability properties exhibited by the films obtained following FFS treatment with TGase confirmed the promising use of the NsDSC-based material mostly for sheet mulching. In fact, the observed marked decrease in the barrier effect of the cross-linked films to both carbon dioxide and oxygen should allow a more active gas exchange without significantly influencing their poor water vapor (WV) permeability (Table 2). 


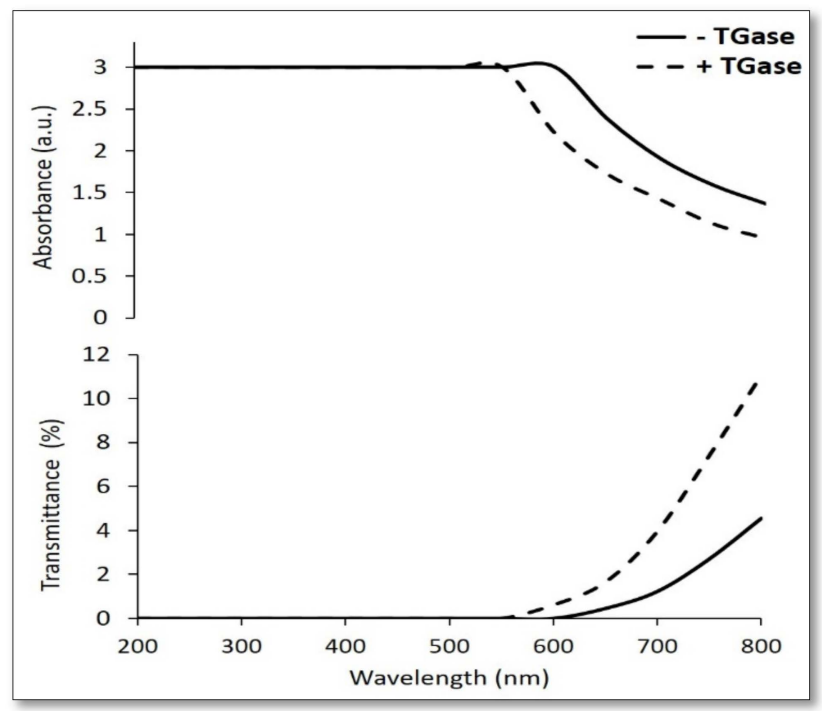

Figure 6. Absorbance and transmittance of films obtained from Nigella sativa defatted seed cake (NsDSC) at pH 8.0 with $20 \%$ glycerol (GLY) after incubation of film forming solutions (FFSs) in the absence or presence of transglutaminase (TGase, $20 \mathrm{U} / \mathrm{g}$ protein). Further experimental details are given in the text.

Table 2. Gas and water vapor (WV) barrier properties of $20 \%$ glycerol (GLY)-containing protein concentrate (PC, $400 \mathrm{mg}$ ) films obtained at $\mathrm{pH} 8.0$ after film forming solutions (FFS) incubation in the absence or presence of transglutaminase (TGase, $20 \mathrm{U} / \mathrm{g}$ protein). Further experimental details are given in the text.

\begin{tabular}{cccc}
\hline Film & $\begin{array}{c}\mathrm{CO}_{2} \\
\left(\mathbf{c m}^{3} \mathbf{m m ~ m}\right.\end{array}$ & $\begin{array}{c}\mathbf{O}_{2} \\
\mathbf{d a y}^{-1}\end{array}$ & $\begin{array}{c}\text { WV } \\
\mathbf{k P a}\end{array}$ \\
\hline - TGase & $1.1 \pm 0.2$ & $0.04 \pm 0.01$ & $0.004 \pm 0.001$ \\
\hline + TGase & $4.6 \pm 0.7^{*}$ & $4.16 \pm 0.13^{*}$ & $0.002 \pm 0.001$ \\
\hline
\end{tabular}

* Significantly different values as compared to those obtained under the same experimental conditions in the absence of TGase $(p<0.05)$.

Figure 7 shows the surface and cross-section morphology of the films containing 20\% GLY and produced at $\mathrm{pH} 8.0$ after FFS incubation in the absence or presence of TGase (20 U/g protein). Scanning electron microscopy (SEM) images indicate a smoother surface and a more continuous and homogeneous microstructure of the cross-section of the NsDSC-based material obtained after FFS treatment with TGase, thus explaining the effect of the enzyme on the film mechanical and barrier properties.

It should be emphasized that the effects of the cross-links produced by TGase on the different properties of the protein-based films were extremely variable depending on the specific structural characteristics of the single proteins involved in the enzymatic reaction. In fact, as far as both mechanical and barrier properties are concerned, sometimes increases and other times decreases in the values of the individual measured parameters (TS, EB, and YM) were reported. The same variability was observed when permeabilities to gases or water vapor were analyzed in films containing different proteins able to act as TGase substrates [11,26,27,30,33-38].

Finally, all the NsDSC-derived films exhibited, similarly to previously produced Vicia ervilia seed protein-based films [27,39], a clear antimicrobial activity tested towards Staphylococcus aureus. However, the inhibition zones produced by films prepared following FFS treatment with TGase were more regular and wider (Figure 8A), probably due to a more homogeneous diffusion of bioactive agents, such as polyphenols, tannins, and flavonoids, from the film cross-linked protein network. Moreover, a loopful of bacteria taken from the inhibition zones showed different arrangements, after Gram staining, when the two different kinds of film were analyzed (Figure 8B). Bacteria around films derived 
from FFSs treated with TGase were disintegrated and less condense with loose cells, probably as a consequence of a more homogeneous distribution into the cross-linked protein network of the bioactive agents possessing antimicrobial activity.

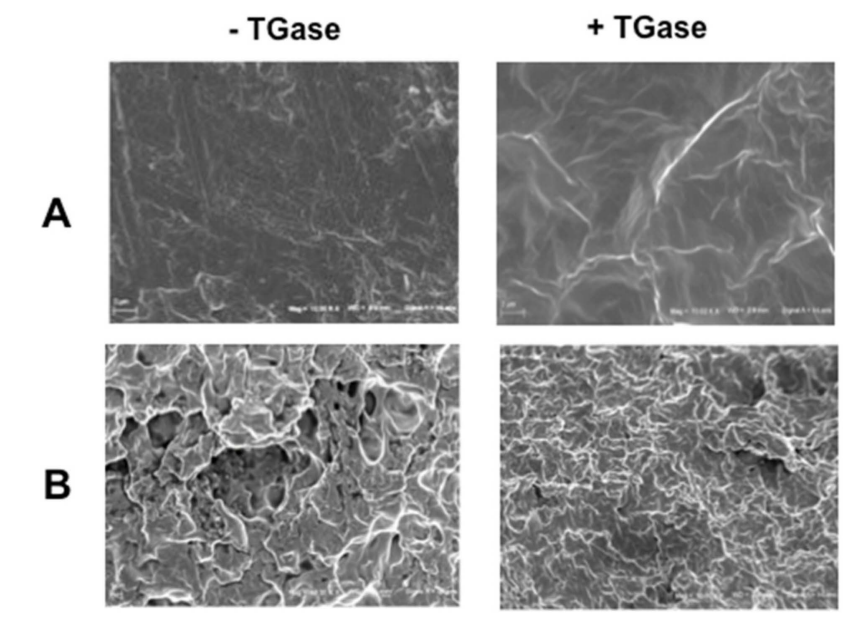

Figure 7. SEM analysis (10,000× magnification) of the surfaces (A) and cross-sections (B) of Nigella sativa defatted seed cake (NsDSC)-derived films obtained in the absence (A) and presence (B) of transglutaminase (TGase)

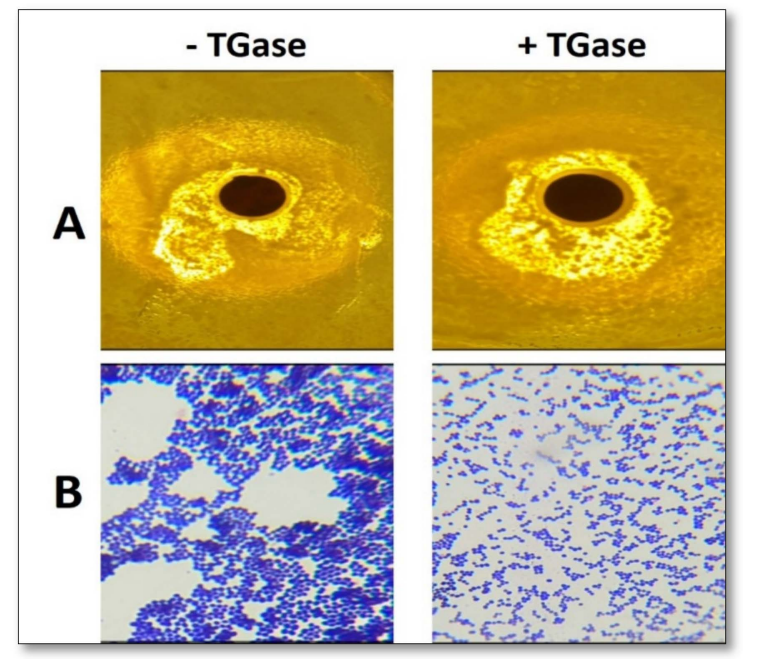

Figure 8. Antimicrobial properties of $20 \%$ glycerol (GLY)-containing protein concentrate (PC, $400 \mathrm{mg}$ ) films obtained from Nigella sativa defatted seed cake (NsDSC) at pH 8.0 after incubation of film forming solutions (FFSs) in the absence or presence of transglutaminase (TGase, $20 \mathrm{U} / g$ protein). The biological effect was evaluated on Staphylococcus aureus from American Type Culture Collection (ATCC) 25923 foodborne pathogenic bacterium by analyzing the growth of cells in direct contact with the film. Cells grown around PC films on mannitol salt agar after $18 \mathrm{~h}$ (A), Gram stain of the bacteria around the PC films (B). Further experimental details are given in the text.

\section{Materials and Methods}

\subsection{Materials}

NsDSC was purchased from Alhathnawi General Trade Co. (Jenin, Palestine). GLY (about 87\%) was supplied from the Merck Chemical Company (Darmstadt, Germany), whereas TGase (Activa WM), derived from the culture of Streptoverticillium sp., was supplied by Prodotti Gianni SpA (Milano, Italy). All other chemicals and solvents used in this study were analytical-grade commercial products. Bacterial strain Staphylococcus aureus, from American Type Culture Collection (ATCC 25923), was 
granted by Dr. M. Alqadi, An-Najah National University. BBL ${ }^{\text {TM }}$ mannitol salt agar (MSA) was purchased from Becton Dickinson and Company, France.

\subsection{NsDSC Protein Extraction}

PC was obtained from NsDSC by acid base extraction method as previously described [10] with some modifications. Dry NsDSC was ground using a rotary mill (Grindomix GM200, Retsch GmbH, Haan, Germany) at a speed of $1200 \mathrm{rpm}$. for $5 \mathrm{~min}$ and the powder was dispersed in distilled water $(1: 10, w / v)$, brought to $\mathrm{pH} 12.0$ with $1 \mathrm{~N} \mathrm{NaOH}$ and stirred at medium speed for $2 \mathrm{~h}$ at room temperature. After centrifugation at $4000 \mathrm{rpm}$ for $20 \mathrm{~min}$, the supernatant was collected and the $\mathrm{pH}$ adjusted at 5.4 by $1 \mathrm{~N} \mathrm{HCl}$ to form a precipitate which was then separated by centrifugation at $4000 \mathrm{rpm}$ for $20 \mathrm{~min}$. The pellet was then poured and uniformly distributed on a plastic plate and dried at $30{ }^{\circ} \mathrm{C}$ and $20 \%$ Relative Humidity ( $\mathrm{RH})$. The obtained PC was finally ground and the protein content (44\%) was determined by the Kjeldahl's method [40] using a nitrogen conversion factor of 6.25.

\subsection{Titration of $P C$ from NsDSC}

Z-average and zeta potential values of PC dissolved in distilled water $(0.1 \mathrm{mg} / \mathrm{mL})$ were determined by a Zetasizer Nano-ZSP $\left(\right.$ Malvern ${ }^{\circledR}$, Worcestershire, UK) equipped with an automatic titrator unit (MPT-2). The device was equipped with a helium-neon laser of $4 \mathrm{~mW}$ output power operating at the fixed wavelength of $633 \mathrm{~nm}$ (wavelength of laser red emission). The instrument software programmer calculated the zeta potential through the electrophoretic mobility by applying a voltage of $200 \mathrm{mV}$ using the Henry equation. The $\mathrm{pH}$ value of $\mathrm{PC}$ solution was adjusted at $\mathrm{pH} 12.0$ by using $1.0 \mathrm{~N} \mathrm{NaOH}$ and then the titration was carried out from $\mathrm{pH} 12.0$ to $\mathrm{pH} 2.0$ by adding 1.0, 0.5 , and $0.1 \mathrm{~N} \mathrm{HCL}$ as titrant solution under constant stirring at $25^{\circ} \mathrm{C}$. Z-average and zeta potential values were measured at each $\mathrm{pH}$ value in triplicate $[10,41]$.

\subsection{FFSs Preparation and Casting}

To prepare the different FFSs, $\mathrm{PC}$ was dissolved in distilled water $(4 \mathrm{~g} / 100 \mathrm{~mL})$ and the $\mathrm{pH}$ value was adjusted to $\mathrm{pH} 12.0$ by using $1 \mathrm{~N} \mathrm{NaOH}$ under constant stirring until the powder was completely solubilized. In preliminary experiments, PC solutions were added with different GLY amounts $(10 \%-50 \% v / w$ protein) to find out the minimal GLY amount needed to obtain handleable films. Further experiments were carried out by adding $20 \%$ GLY ( $v / w$ protein) to aliquots of PC solution which were then incubated at $37^{\circ} \mathrm{C}$ for $2 \mathrm{~h}$ at $\mathrm{pH} 8.0$ in the absence or presence of microbial TGase (20 Units/g protein). All the FFSs ( $50 \mathrm{~mL}$ each containing $400 \mathrm{mg}$ protein) were finally casted at different $\mathrm{pH}$ values $(6,8,10$, and 12$)$ and, after $48 \mathrm{~h}$, the dried films were analyzed.

\subsection{Sodium Dodecyl Sulphate Polyacrylamide Gel Electrophoresis (SDS-PAGE)}

The $250 \mu \mathrm{L}$ of sample buffer (15 mM Tris-HCl, pH 6.8, containing 0.5\% (w/v) SDS, 2.5\% (v/v) GLY, $200 \mathrm{mM} \beta$-mercaptoethanol, and $0.003 \%(w / v)$ bromophenol blue), were added to aliquots of $0.1 \mathrm{~mL}$ of each FFS previously incubated at $37^{\circ} \mathrm{C}$ for $2 \mathrm{~h}$ at $\mathrm{pH} 8.0$ in the absence or presence of TGase (10 or $20 \mathrm{U} / g$ protein), and analyzed by $12 \%$ SDS-PAGE. In all cases, SDS-PAGE was performed as previously described [42], at a constant voltage ( $80 \mathrm{~V}$ for $2-3 \mathrm{~h}$ ). Coomassie Brilliant Blue R250 (Bio-Rad, Segrate, Milan, Italy) was used to stain the proteins and Bio-Rad Precision Protein Standards were simultaneously run as molecular weight markers.

\subsection{Film Characteristics}

NsDSC films prepared with $20 \%$ GLY in the presence or absence of TGase were cut into $1-\mathrm{cm} \times 4-\mathrm{cm}$ strips placed in a quartz cuvette and their light-barrier properties were determined by measuring their light absorption at wavelengths ranging from $200 \mathrm{~nm}$ to $800 \mathrm{~nm}$, with a scan rate of $300 \mathrm{~nm} / \mathrm{min}$, using a Jenway UV-VIS spectrophotometer 6705 (Cole-Parmer Ltd., Staffordshire, UK). Film TS, EB, 
and YM values were determined in six specimens for each films (1 $\mathrm{kN}$ load and $5 \mathrm{~mm} / \mathrm{min}$ speed), as previously reported by using an Instron universal testing instrument model No. 5543A (Instron Engineering Corp., Norwood, MA, USA) [43] after their conditioning at $25{ }^{\circ} \mathrm{C}$ and $50 \% \mathrm{RH}$ for $2 \mathrm{~h}$ by placing the film samples into a desiccator over a saturated solution of $\mathrm{Mg}\left(\mathrm{NO}_{3}\right)_{2} \cdot 6 \mathrm{H}_{2} \mathrm{O}$ before being tested. Film thickness measurements were performed in six different points of each film with a digital micrometer (DC-516, sensitivity $0.1 \mu \mathrm{m}$ ). Film permeabilities to $\mathrm{O}_{2}, \mathrm{CO}_{2}$, and water vapor (WV) were detected in triplicate for each film, by using a Total Perm apparatus (ExtraSolution s.r.l., Pisa, Italy) endowed with barometric compensation, at $25{ }^{\circ} \mathrm{C}$ and $50 \% \mathrm{RH}$ and at partial pressure differences of 1 bar for $\mathrm{O}_{2}$ and $\mathrm{CO}_{2}$ measurements and of 16 mbar for $\mathrm{WV}$, respectively. In addition, aluminum masks were used with the aim to reduce the film test area to $5 \mathrm{~cm}^{2}$ [44-46]. NsDSC film surface and cross-section ultrastructure was examined by SEM. Films were cut using scissors, mounted on stub, and sputter-coated with platinum-palladium (Denton Vacuum Desk V) before observation with Supra 40 ZEISS (EHT $=5.00 \mathrm{kV}$, detector in lens).

\subsection{Film Antimicrobial Activity}

Bacterial strain of Staphylococcus aureus (ATCC 25923) was activated twice in a nutrient broth to reach a cell concentration corresponding to 0.5 turbidity at $600 \mathrm{~nm}$, spectrophotometrically determined by measuring the amount of light scattered by the culture. Then, the cells were transferred to the selective media of mannitol salt agar to insure purity. A separated colony was retransferred to nutrient broth and incubated at $37^{\circ} \mathrm{C}$ for $18 \mathrm{~h}$ to reach $0.5 \pm 0.02$ turbidity equivalent. Discs (5-mm diameter) obtained by cutting each film sample were used to evaluate the inhibition zones of Staphylococcus aureus. Then, $0.2 \mathrm{~mL}$ of the nutrient broth containing bacterial cells was loaded on the mannitol salt agar Petri dishes (five discs of each sample were distributed over the Petri dish) and, then, all dishes were incubated at $37^{\circ} \mathrm{C}$ for $18 \mathrm{~h}$. Finally, the inhibition zones were observed and evaluated.

\subsection{Statistical Analysis}

JMP software 10.0 (SAS Institute, Cary, NC, USA), one way ANOVA, and the least significant difference test for mean comparisons were used. Differences were considered to be significant at $p<0.05$.

\section{Conclusions}

The development of new bio-materials from agro-industrial wastes is one of the major technological challenges, and the defatted seed cakes, by-products of oil producing industry, may be good and cheap sources of both energy and protein. The present study focused on the possibility to obtain potentially useful protein-based biodegradable/edible films by recovery and formulation procedures from seed oil cakes, offering a sustainable and eco-friendly option to produce novel prototypes for applications others than animal feed, fertilizers, or culinary food. Thus, innovative and biodegradable/edible black films from Nigella sativa defatted seed cakes were obtained. The GLY-plasticized films containing enzymatically cross-linked proteins showed mechanical and barrier properties, as well as antimicrobial ones, compatible with a possible re-use of the Nigella sativa defatted seed cakes as a renewable source to produce bioplastics of food and agricultural interest. Potential applications of the obtained bio-materials (e.g., coating/wrapping of different fabricated foods for shelf-life extension, protection of fruits and vegetables by control of maturation, soil mulching for a more sustainable agricultural production) deserve to be investigated.

Author Contributions: Conceptualization, M.S., M.A., and R.P.; methodology, M.S., M.A., C.S., and P.D.P.; investigation, M.S., M.A., and M.C.; writing—original draft preparation, M.S. and M.A.; writing-review and editing, R.P.; supervision, P.D.P., C.S., and R.P.; funding acquisition, M.S., M.A., and P.D.P. All authors have read and agreed to the published version of the manuscript. 
Funding: This research was funded by the Italian Ministries of Foreign Affairs and International Cooperation (IV Programma Quadro di Cooperazione Italia/Messico, 2017, (CUP: E62D15002620001), and by An-Najah National University (grant number ANNU-1819-Sc012).

Acknowledgments: The authors acknowledge "Alhathnawi General Trade Co" (Jenin, Palestine) for the supply of the Nigella sativa defatted seed cakes.

Conflicts of Interest: The authors declare no conflict of interest.

\section{References}

1. Porta, R. The plastics sunset and the bio-plastics sunrise. Coatings 2019, 9, 526. [CrossRef]

2. Valdés, A.; Burgos, N.; Jiménez, A.; Garrigós, M. Natural pectin polysaccharides as edible coatings. Coatings 2015, 5, 865-886. [CrossRef]

3. Baron, R.D.; Pérez, L.L.; Salcedo, J.M.; Córdoba, L.P.; Sobral, P.J. Production and characterization of films based on blends of chitosan from blue crab (Callinectes sapidus) waste and pectin from Orange (Citrus sinensis Osbeck) peel. Int. J. Biol. Macromol. 2017, 98, 676-683. [CrossRef] [PubMed]

4. Iamareerat, B.; Singh, M.; Sadiq, M.B.; Anal, A.K. Reinforced cassava starch based edible film incorporated with essential oil and sodium bentonite nanoclay as food packaging material. J. Food Sci. Technol. 2018, 55, 1953-1959. [CrossRef] [PubMed]

5. Gustafsson, J.; Landberg, M.; Bátori, V.; Åkesson, D.; Taherzadeh, M.J.; Zamani, A. Development of bio-based films and 3D objects from apple pomace. Polymers 2019, 11, 289. [CrossRef] [PubMed]

6. Ket-On, A.; Pongmongkol, N.; Somwangthanaroj, A.; Janjarasskul, T.; Tananuwong, K. Properties and storage stability of whey protein edible film with spice powders. J. Food Sci. Technol. 2016, 53, 2933-2942. [CrossRef]

7. Abdalrazeq, M.; Giosafatto, C.V.L.; Esposito, M.; Fenderico, M.; Di Pierro, P.; Porta, R. Glycerol-plasticized films obtained from whey proteins denatured at alkaline $\mathrm{pH}$. Coatings 2019, 9, 322. [CrossRef]

8. Mariniello, L.; Di Pierro, P.; Esposito, C.; Sorrentino, A.; Masi, P.; Porta, R. Preparation and mechanical properties of edible pectin-soy flour films obtained in the absence or presence of transglutaminase. J. Biotechnol. 2003, 102, 191-198. [CrossRef]

9. Fathi, N.; Almasi, H.; Pirouzifard, M.K. Effect of ultraviolet radiation on morphological and physicochemical properties of sesame protein isolate based edible films. Food Hydrocolloid. 2018, 85, 136-143. [CrossRef]

10. Sabbah, M.; Di Pierro, P.; Giosafatto, C.V.L.; Esposito, M.; Mariniello, L.; Regalado- Gonzales, C.; Porta, R. Plasticizing effects of polyamines in protein-based films. Int. J. Mol. Sci. 2017, 18, 1026. [CrossRef]

11. Porta, R.; Di Pierro, P.; Rossi-Marquez, G.; Mariniello, L.; Kadivar, M.; Arabestani, A. Microstructure and properties of bitter vetch (Vicia ervilia) protein films reinforced by microbial transglutaminase. Food Hydrocoll. 2015, 50, 102-107. [CrossRef]

12. Porta, R.; Di Pierro, P.; Sabbah, M.; Regalado Gonzales, C.; Mariniello, L.; Kadivar, M.; Arabestani, A. Blend films of pectin and bitter vetch (Vicia ervilia) proteins: Properties and effect of transglutaminase. Innov. Food Sci. Emerg. Technol. 2016, 36, 245-251. [CrossRef]

13. Toma, C.C.; Olah, N.K.; Vlase, L.; Mogoşan, C.; Mocan, A. Comparative studies on polyphenolic composition, antioxidant and diuretic effects of Nigella sativa L. (Black Cumin) and Nigella damascena L. (Lady-in-a-Mist) seeds. Molecules 2015, 26, 9560-9574. [CrossRef] [PubMed]

14. Kadam, D.; Shah, N.; Palamthodi, S.; Lele, S.S. An investigation on the effect of polyphenolic extracts of Nigella sativa seedcake on physicochemical properties of chitosan-based films. Carbohydr. Polym. 2018, 15, 347-355. [CrossRef] [PubMed]

15. Nergiz, C.; Ötleş, S. Chemical composition of Nigella sativa L. seeds. Food Chem. 1993, 48, 259-261. [CrossRef]

16. Salem, M.L. Immunomodulatory and therapeutic properties of the Nigella sativa L. seed. Int. Immunopharmacol. 2005, 5, 1749-1770. [CrossRef] [PubMed]

17. Mariod, A.A.; Ibrahim, R.M.; Ismail, M.; Ismail, N. Antioxidant activity and phenolic content of phenolic rich fractions obtained from black cumin (Nigella sativa) seedcake. Food Chem. 2009, 116, 306-312. [CrossRef]

18. Joint FAO/WHO Food Standards Programme Codex Committee on Spices and Culinary Herbs. 2014. Available online: http://www.fao.org/tempref/codex/meetings/ccsch/ccsch1/crds/sc01_crd11x.pdf (accessed on 27 January 2020). 
19. Ahmad, A.; Husain, A.; Mujeeb, M.; Khan, S.A.; Najmi, A.K.; Siddique, N.A.; Damanhouri, Z.A.; Anwar, F. A review on therapeutic potential of Nigella sativa: A miracle herb. Asian Pac. J. Trop. Biomed. 2013, 3, 337-352. [CrossRef]

20. Yimer, E.M.; Tuem, K.B.; Karim, A.; Ur-Rehman, N.; Anwar, F. Nigella sativa L. (Black Cumin): A promising natural remedy for wide range of illnesses. Evid.-Based Complementary Altern. Med. 2019, 2019, 16-31. [CrossRef]

21. Pandey, A.K.; Dhakal, M.R. Phytomelanin in compositae. Curr. Sci. 2001, 80, 933-940.

22. Eid, A.M.; Elmarzugi, N.A.; Abu Ayyash, L.M.; Sawafta, M.N.; Daana, H.I. A Review on the cosmeceutical and external applications of Nigella sativa. J. Trop. Med. 2017. [CrossRef] [PubMed]

23. Özdemir, Ö.; Keleş, Y. Extraction, purification, antioxidant properties and stability conditions of phytomelanin pigment on the sunflower seeds. Int. J. Second Metab. 2018, 5, 140-148.

24. Abd El-Hack, M.E.; Alagawany, M.; Saeed, M.; Arif, M.; Arain, M.A.; Bhutto, Z.A.; Fazlani, S.A. Effect of gradual substitution of soybean meal by Nigella sativa meal on growth performance, carcass traits and blood lipid profile of growing Japanese quail. J. Anim. Feed Sci. 2016, 25, 244-249. [CrossRef]

25. Rossi Marquez, G.; Di Pierro, P.; Mariniello, L.; Esposito, M.; Giosafatto, C.V.L.; Porta, R. Fresh-cut fruit and vegetable coatings by transglutaminase-crosslinked whey protein/pectin edible films. LWT-Food Sci. Technol. 2017, 75, 124-130. [CrossRef]

26. Sabbah, M.; Giosafatto, C.V.L.; Esposito, M.; Di Pierro, P.; Mariniello, L.; Porta, R. Transglutaminase cross-linked edible films and coatings for food applications. In Enzymes in Food Biotechnology, 1st ed.; Kuddus, M., Ed.; Academic Press: New York, NY, USA, 2019; pp. 369-388.

27. Fernandez-Bats, I.; Di Pierro, P.; Villalonga-Santana, R.; Garcia-Almendarez, B.; Porta, R. Bioactive mesoporous silica nanocomposite films obtained from native and transglutaminase-crosslinked bitter vetch proteins. Food Hydrocoll. 2018, 82, 106-115. [CrossRef]

28. Sabbah, M.; Esposito, M.; Di Pierro, P.; Giosafatto, C.V.L.; Mariniello, L.; Porta, R. Insight into zeta potential measurements in biopolymer film preparation. J. Biotechnol. Biomater. 2016. [CrossRef]

29. Gaspar, A.L.; de Góes-Favoni, S.P. Action of microbial transglutaminase (MTGase) in the modification of food proteins: A review. Food Chem. 2015, 15, 315-322. [CrossRef]

30. Giosafatto, C.V.L.; Al-Asmar, A.; D’Angelo, A.; Roviello, V.; Esposito, M.; Mariniello, L. Preparation and characterization of bioplastics from grass pea flour cast in the presence of microbial transglutaminase. Coatings 2018, 8, 435. [CrossRef]

31. Mariniello, L.; Giosafatto, C.V.L.; Di Pierro, P.; Sorrentino, A.; Porta, R. Synthesis and resistance to in vitro proteolysis of transglutaminase cross-linked phaseolin, the major storage protein from Phaseolus vulgaris. J. Agric. Food Chem. 2007, 55, 4717-4721. [CrossRef]

32. Steinmetz, Z.; Wollmann, C.; Schaefer, M.; Buchmann, C.; David, J.; Tröger, J.; Muñoz, K.; Frör, O.; Schaumann, G.E. Plastic mulching in agriculture. Trading short-term agronomic benefits for long-term soil degradation? Sci. Tot. Environ. 2016, 550, 690-705. [CrossRef]

33. Porta, R.; Di Pierro, P.; Sorrentino, A.; Mariniello, L. Promising perspectives for transglutaminase in "bioplastics" production. J. Biotechnol. Biomater. 2011. [CrossRef]

34. Giosafatto, C.V.L.; Di Pierro, P.; Gunning, P.; Mackie, A.; Porta, R.; Mariniello, L. Trehalose-containing hydrocolloid edible films prepared in the presence of transglutaminase. Biopolymers 2014, 101, 931-937. [CrossRef] [PubMed]

35. Giosafatto, C.V.L.; Di Pierro, P.; Gunning, P.; Mackie, A.; Porta, R.; Mariniello, L. Characterization of citrus pectin edible films containing transglutaminase-modified phaseolin. Carbohydr. Polym. 2014, 106, 200-208. [CrossRef] [PubMed]

36. AL-Hassan, A.A.; Norziah, M.H. Effect of transglutaminase induced crosslinking on the properties of starch/gelatin films. Food Packag. Shelf Life. 2017, 13, 15-19. [CrossRef]

37. Escamilla-García, M.; Delgado-Sánchez, L.F.; Ríos-Romo, R.A.; García-Almendárez, B.E.; Calderón-Domínguez, G.; Méndez-Méndez, J.V.; Amaro-Reyes, A.; Di Pierro, P.; Regalado-González, C. Effect of transglutaminase cross-linking in protein isolates from a mixture of two quinoa varieties with chitosan on the physicochemical properties of edible films. Coatings 2019, 9, 736. [CrossRef]

38. Cheng, S.; Wang, W.; Li, Y.; Gao, G.; Zhang, K.; Zhou, J.; Wu, Z. Cross-linking and film-forming properties of transglutaminase-modified collagen fibers tailored by denaturation temperature. Food Chem. 2019, 271, 527-535. [CrossRef] 
39. Sabbah, M.; Di Pierro, P.; Dell'Olmo, E.; Arciello, A.; Porta, R. Improved shelf-life of Nabulsi cheese wrapped with hydrocolloid films. Food Hydrocolloid. 2019, 96, 29-35. [CrossRef]

40. American Association of Cereal Chemists (AACC). Approved Methods of AACC; The Association: St. Paul, MN, USA, 2003; Available online: https://methods.aaccnet.org/default.aspx (accessed on 27 January 2020).

41. Sabbah, M.; Di Pierro, P.; Cammarota, M.; Dell'Olmo, E.; Arciello, A.; Porta, R. Development and properties of new chitosan-based films plasticized with spermidine and/or glycerol. Food Hydrocolloid. 2019, 87, 245-252. [CrossRef]

42. Laemmli, U.K. Cleavage of structural proteins during the assembly of the head of Bacteriophage T4. Nature 1970, 227, 680-985. [CrossRef]

43. ASTM D882-97. Standard Test. Method for Tensile Properties of Thin Plastic Sheeting; ASTM: Philadelphia, PA, USA, 1997; Available online: https://compass.astm.org/download/D882-97.26873.pdf (accessed on 27 January 2020).

44. ASTM D3985-05. Standard Test Method for Oxygen Gas Transmission Rate through Plastic Film and Sheeting Using a Colorimetric Sensor; ASTM International: West Conshohocken, PA, USA, 2010; Available online: https://compass.astm.org/download/D3985-05R10e1.2856.pdf (accessed on 27 January 2020).

45. ASTM F2476-13. Standard Test. Method for the Determination of Carbon Dioxide Gas. Transmission Rate (CO $\mathrm{CR}_{2}$ through Barrier Materials Using an Infrared Detector; ASTM International: West Conshohocken, PA, USA, 2013; Available online: https://compass.astm.org/download/F2476.9621.pdf (accessed on 27 January 2020).

46. ASTM F1249-13. Standard Test. Method for Water Vapor Transmission Rate Through Plastic Film and Sheeting Using a Modulated Infrared Sensor; ASTM International: West Conshohocken, PA, USA, 2013; Available online: https://compass.astm.org/download/F1249.13215.pdf (accessed on 27 January 2020).

(C) 2020 by the authors. Licensee MDPI, Basel, Switzerland. This article is an open access article distributed under the terms and conditions of the Creative Commons Attribution (CC BY) license (http://creativecommons.org/licenses/by/4.0/). 